\title{
CERN's head rejects mismanagement claims
}

\section{Alison Abbott, Munich}

Luciano Maiani, director general of CERN, the European particle physics laboratory in Geneva, has denied that mismanagement has led to cost overruns on the Large Hadron Collider (LHC) project.

CERN shocked its 20 member states last month by announcing cost overruns of SFr480 million (US\$296 million) on the SFr2.6-billion project, and of a further SFr370 million on CERN's core budget during the LHC's construction period (see Nature 413, 441;2001).

"We've always been in control of developments," says Maiani. "This is a high-tech project of extreme complexity, and an overrun of $18 \%$ is not unreasonable."

But Maiani, who was head of the Italian Nuclear Physics Institute before taking up his position at CERN in 1999, accepts the charge that his management team failed to reveal the scale of the problem as soon as it became apparent in the spring. "We've learnt a hard lesson about the need for openness," he says.

The problems should have been identified last year, when the first cost-tocompletion estimates for the LHC were due, Maiani admits. But he says that he was distracted at the time by preliminary results suggesting that detectors at the Large Electron-Positron (LEP) collider, which the LHC will replace, had picked up signatures of the Higgs boson - the fundamental particle that the LHC is designed to find.

CERN researchers were then torn between extending the LEP's life in a bid to confirm the finding, or switching it off to start work on the LHC. Maiani decided to pull the plug on the LEP - rightly as it turned out, as reanalysis of the preliminary results indicated little likelihood that the Higgs particle had actually been spotted. "The LEP decision fully absorbed the energy

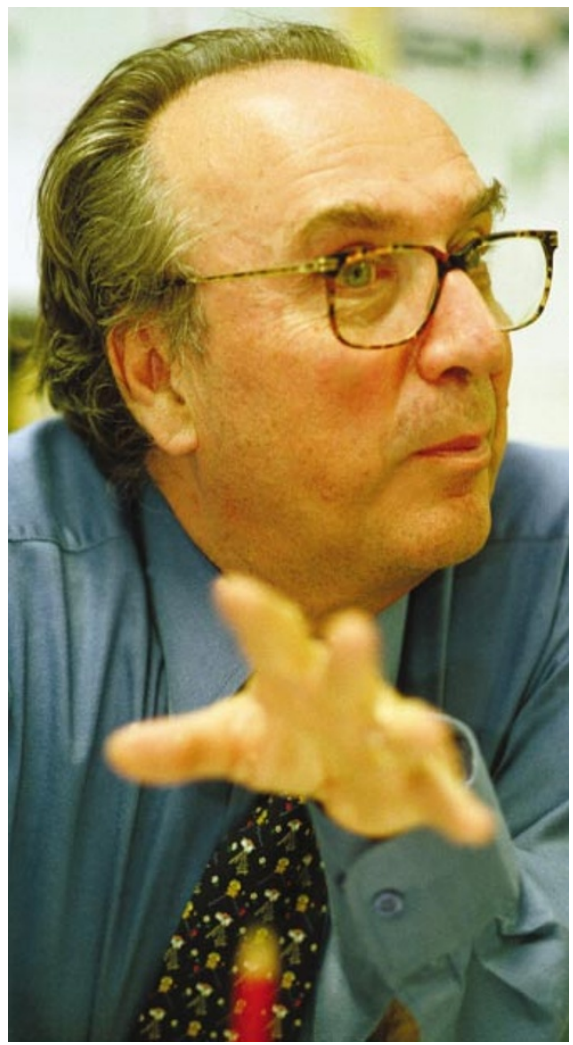

A hard lesson learnt: Maiani accepts that delaying admission of financial problems was a mistake. of both the scientists and the administration," says Maiani.

A major project review was begun in March of this year, and final quotes for the supply of the LHC's 1,000 or so superconducting magnets — which Maiani decided to await before completing the review - were received from contractors in August.

"If I had the time again, I would have discussed the emerging financial difficulties with our scientists and with member-state delegations," he says. "But I decided to wait until we had solid numbers to discuss. This was probably the wrong decision - it backfired on us."

More unreasonable than the cost overrun, in Maiani's view, is the fact that the LHC project had to be launched on a tight budget with no financial contingency.

Asked how he will now proceed, Maiani warns of austerity ahead. "There's no doubt that we will have to streamline all of CERN's activities behind the LHC," he says. Smaller programmes in heavy-ion, neutrino and antimatter research will have to be cut back, and other laboratory costs will be reduced. He also suggests that loans could be sought to buy time - and hopes that member states will increase their contributions.

Maiani says he is confident that the project will get back on track, and even claims that last year's decision to turn off the LEP was much more difficult for him than resolving the new financial difficulties, which he insists are inherent in high-technology projects such as this. The technological progress of the LHC remains "rock-solid”, he says.

\section{Sanger Centre welcomes gene funds with a new name}

\section{David Adam, London}

The Sanger Centre near Cambridge, UK, has announced a five-year plan to spend $\mathfrak{E 3 0 0}$ million (US $\$ 435$ million) on research to follow up on its role in the publication, earlier this year, of the human genome sequence (see Nature 409, 860-923; 2001).

The plan, which will be paid for by the Wellcome Trust, the world's largest biomedical research charity, includes increased efforts to understand gene function and expression, to develop bioinformatics tools and to draw comparisons between humans and model organisms such as the mouse. The centre is also changing its name to become the Wellcome Trust Sanger Institute.

"The new funding will allow the institute to make a contribution to global science and medicine as significant as its contribution to the Human Genome Project," says institute director Allan Bradley. "We will bring biology to the genome and translate the enormous amount of information encoded in our DNA into an understanding of gene function."

According to the new plan, the institute will work to identify as many genes as possible within the human genome and to predict their functions, as well as locating the regions that control their expression. The laboratory will also target disease genes, including those that contribute to cancers, building on a major project already under way to search for the genetic mutations that cause them.

One new project aims to identify genes on the $\mathrm{X}$ chromosome that are involved in primary or non-specific X-linked mental retardation, one of the most common genetic disorders. Another will focus on uncovering the genetic basis of disorders that have multiple genetic causes, such as diabetes, asthma and other allergies. This association study will use a map of 'haplotype' groups - inherited blocks of genetic markers - to be prepared by an international consortium of labs and biotech companies (see Nature 412, $105 ; 2001$ ).

The institute will also establish a genetics programme to further the understanding of the role of genes in mouse development and physiology, and in human disease. "These new initiatives will complement and build on the institute's considerable strengths in genome data generation, automation and bioinformatics," says Mike Dexter, director of the Wellcome Trust. 